\section{T Cell Signal Transduction and the Role of CD7 in Costimulation}

\begin{abstract}
The complex cellular interactions that govern the mammalian immune response are now known to include specific receptor/ligand interactions, recruitment of intracellular signaling molecules, activation of both kinases and phosphatases, and redistribution of macromolecular complexes into specific subcellular membrane locations that, in aggregate, result in transcriptional activation. While the TCR-CD3 signal is critical for activation of the resting $\mathrm{T}$ cell, it alone is not sufficient to initiate transcriptional activation or generate an effective immune response. A number of other coreceptor molecules, including CD4, CD8, and CD28, have now been characterized that also play important roles in initiating or amplifying the activation of the T cell. A $40 \mathrm{kDa}$ member of the immunoglobulin superfamily, the CD7 molecule, has also been shown to have costimulatory activity and to induce tyrosine and lipid kinase activities. Here we will review the signaling pathways initiated by TCR, CD28, and CD7, as well as the functional consequences of signal transduction through these receptors.
\end{abstract}

Ross Stillwell Barbara E. Bierer

Laboratory of Lymphocyte Biology, Laboratory Research Program, Division of Intramural Research, National Heart, Lung, and Blood Institute, National Institutes of Health, Bethesda, MD

\section{Key Words}

$\mathrm{T}$ cell receptor

CD3

CD7

CD28

Coreceptor

Costimulation

Lymphocyte signal transduction

\section{Introduction}

The mammalian immune response is governed by a number of complex cellular interactions. Central to the initiation of an immune response is the recognition of a foreign peptide antigen by the $T$ cell receptor (TCR). Antigen presenting cells (APC) proteolyze the proteins of invading pathogens to smaller pep- tide fragments that are then bound in the pocket of the major histocompatibility (MHC) proteins in intracellular compartments before being transported to the cell surface. There, the MHC/antigen complex on the APC may be bound by a specific TCR on the responding $\mathrm{T}$ cell. The binding of the MHC antigen complex transmits signals into the responding cell through a cluster of TCR-associated trans- 
membrane proteins termed the $\mathrm{CD} 3$ complex. This event elicits the activation of protein tyrosine kinases (PTKs) and calcium release that in turn initiate a cascade of signals, eventually resulting in the expression of new genes necessary for responding to the foreign antigen, including interleukin 2 (IL-2) and its receptor $(1,2)$.

Although the TCR-CD3 signal is critical for activation of the resting $\mathrm{T}$ cell, it alone is not sufficient to initiate transcriptional activation or generate an effective immune response. In recent years, a number of other surface molecules have been identified that also play important roles in initiating or amplifying the activation of the T cell. These molecules, termed coreceptors, include CD4, CD8, and $\mathrm{CD} 28$, which each bind to ligands on the APC. The apparent need for ligation of additional coreceptors led to a "two-signal" model of $T$ cell activation. In this model, the first signal is generated through engagement of the TCR-CD3 complex by the specific antigenbearing MHC on the APC, and the second signal may be provided either through a nonspecific T cell surface coreceptor contacting its ligand on the APC (3) or through cytokines in the extracellular milieu. Among the lymphocyte surface coreceptors, CD4 and CD8 are accessory molecules that are activated by binding the MHC class II and class I proteins directly $(4,5)$. CD28 is a surface receptor that is activated by binding to one of its natural ligands on the APC, CD80 (B7.1) or CD86 (B7.2). Coengagement of the TCR together with a costimulatory molecule activates transcription and, concurrently, prevents the induction of $\mathrm{T}$ cell nonresponsiveness, a consequence of TCR-CD3 engagement ("signal one") in the absence of other signals $(6,7)$. Because productive activation of the $T$ cell requires signals in addition to that through the TCR-CD3 complex, the search for and characterization of new candidate costimulatory molecules has become important. The CD7 molecule, a member of the immunoglobulin (Ig) superfamily, is expressed early in lymphocyte and myeloid development and on mature human $\mathrm{T}$ and natural killer (NK) cells. The CD7 polypeptide is a $40 \mathrm{kDa}$ molecule, and a number of monoclonal antibodies (mAbs) directed against the molecule have been generated. Using these anti-CD7 specific mAbs, both costimulatory activity and the induction of tyrosine and lipid kinase activity have been demonstrated. CD7, like CD28, contains a motif within its cytoplasmic domain capable of binding, when phosphorylated, the p85 subunit of phosphoinositide 3 kinase (PI3K). This review will examine the signaling pathways initiated by TCR, CD28, and $\mathrm{CD} 7$, as well as the functional consequences of signal transduction through these receptors. Recent studies detailing the consequences of genetic deletion of the CD7 molecule in mice as well as the identification of a putative cognate ligand for $\mathrm{CD} 7$ will be considered.

\section{T Cell Antigen Receptor Signaling}

The $T$ cell receptor is a member of the immunoglobulin supergene family that exists as a heterodimer of $\alpha$ and $\beta$ or $\gamma$ and $\delta$ subunits, with each subunit possessing a unique amino acid sequence for antigen recognition (8). T cell receptor subunits have short cytoplasmic domains and require the associated CD3 complex of transmembrane molecules to initiate signal transduction following contact of the TCR by the appropriate peptide/MHC complex (9). Whereas the $\mathrm{CD} 3$ proteins do not themselves possess intrinsic kinase activity, the chains of the $\mathrm{CD} 3$ complex, $\gamma, \delta$, $\varepsilon$, and $\zeta-\zeta$ dimers, contain multiple tyrosine-based domains, termed immunoreceptor tyrosine-based activation motifs (ITAMs) that mediate the binding of signaling proteins $(10,11)$. Upon TCR stimulation, PTKs phosphorylate the tyrosines within 


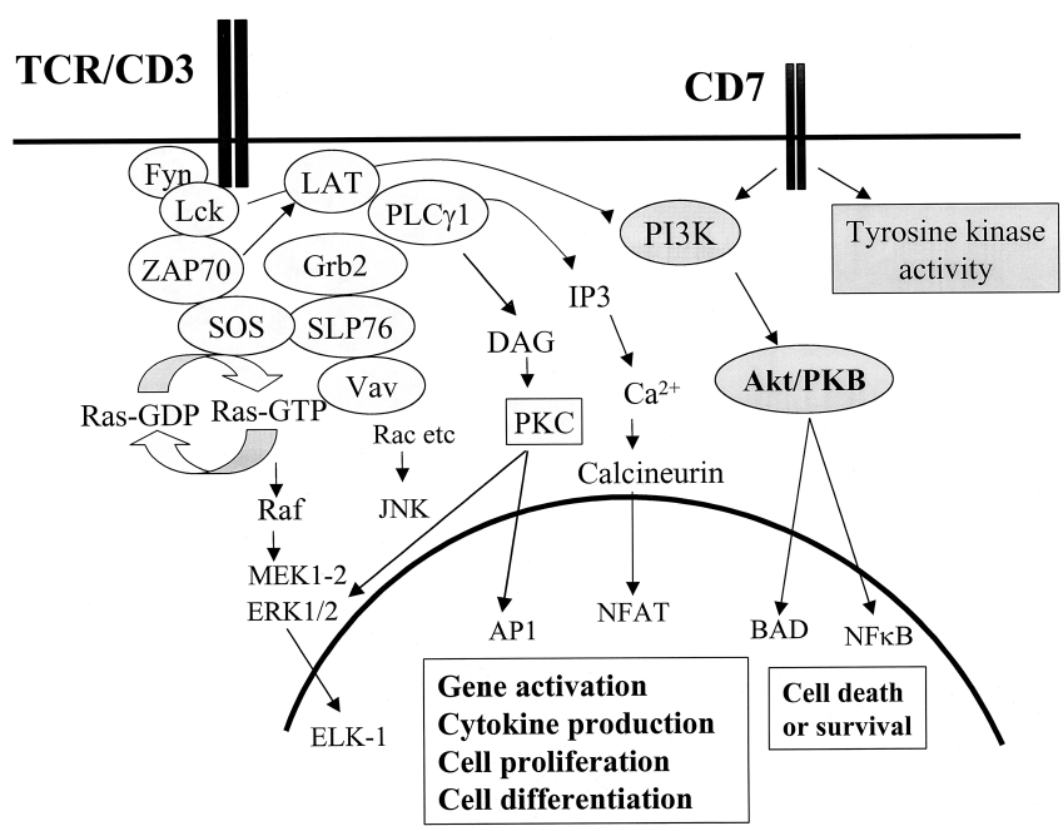

Fig. 1. Events in $T$ cell signal transduction. A general schematic of many of the signaling pathways initiated by the TCR as well as the contribution of CD7 generated signals.

these motifs facilitating the binding of adapter and signaling proteins that contain Src homology 2 (SH2) and PTB domains (12). Thus, the cascade of signals from the stimulated TCR is initiated. Critical components of this cascade are summarized below (Fig. 1).

\section{Protein Tyrosine Kinases}

One of the earliest events in the cascade of signals triggered by TCR engagement is the activation of PTKs. Several distinct families of tyrosine kinases are important in transducing signals from the TCR-CD3 complex. Upon TCR engagement, the Src family members Lck and Fyn are activated and phosphorylate the tyrosines within the ITAM motifs of the CD3 chains $(13,14)$. Lck and Fyn may be constitutively localized to the plasma membrane by their aminoterminal myristoylation modifications; Lck can also bind to the CD4 and CD8 accessory molecules by a cysteine-based motif in its unique aminoterminal region (15-17). CD4 or CD8 contact the MHC molecule essentially concurrently with the TCR and activate Lck (11). Following phosphorylation of the ITAMs, other signaling molecules can then bind to the phosphotyrosine motifs on the CD3 chains utilizing their own SH2 domains (2). Among these ITAM binding proteins are phosphoinositide 3 kinase (PI3K), the adapter protein Shc, and the Syk family tyrosine kinase, ZAP-70 (18-20). Once recruited to the ITAMs, Syk family kinases still require tyrosine phosphorylation by another kinase, possibly Lck, in order to become activated (21). There are at least two other types of PTKs involved in $\mathrm{T}$ cell signaling, the TEC family kinases, Itk and Tec (22,23), and the negative regulatory kinase Csk. Csk phosphorylates a negative regulatory tyrosine in the carboxyterminal region of Src family kinases (discussed below) $(1,24)$. The absence of Itk in mature $\mathrm{T}$ cells leads to a defect in calcium channel function at 
the plasma membrane, correlating with defective phosphorylation of phospholipase C- $\gamma 1$ (PLC- $\gamma 1$ ) following TcR binding (25).

\section{Adapter Molecules}

Once the PTKs associated with the TCR become activated, a number of substrates are phosphorylated, initiating SH2 mediated interactions that bring various components of the signaling machinery into juxtaposition. Many of these interactions are facilitated by adapter molecules that serve as scaffolding for the binding of other molecules, thereby assembling and propagating a signaling cascade without contributing any catalytic activity (11). One critical ZAP-70 substrate is the linker for activated T cells (LAT) molecule, a $36 \mathrm{kDa}$ transmembrane adapter protein with a small extracellular portion (26). The cytoplasmic domain of LAT has multiple tyrosines that become phosphorylated and mediate the binding of phospholipase C- $\gamma 1$ (PLC- $\gamma 1)$, the p85 subunit of PI3K, the cytoplasmic adapter molecules Grb2, Cbl, SLP-76, and Vav, a protein with guanine nucleotide exchange factor activity (26). Grb2 itself serves as a docking site for Sos, a guanine nucleotide exchange factor for Ras. This LAT-Grb2 association may thus serve to link the $\mathrm{T}$ cell receptor to Ras activation $(26,27)$. The LAT association with PLC- $\gamma 1$ may also be a mechanism that initiates the PLC- $\gamma 1$ hydrolysis of PIP $_{2}$ (phosphatidylinositol bis-phosphate) to $\mathrm{IP}_{3}$ (inositol tris-phosphate) and DAG (diacylglycerol), intracellular mediators that facilitate calcium release and $\mathrm{PKC}$ activation, respectively $(26,27)$. Experiments with a LAT-deficient cell line demonstrate that the absence of LAT results in the loss of TCR stimulated PLC- $\gamma 1$, Vav, and SLP-76 phosphorylation (28-30) supporting many of the assertions above.

There are a number of other adapter molecules involved in TCR signal transduction, whose individual and cooperative contributions to T cell activation are still unclear. Shc, an adapter protein composed of an aminoterminal phosphotyrosine binding (PTB) domain, a collagen homology domain $(\mathrm{CH})$, and a carboxyterminal $\mathrm{SH} 2$ domain, can bind to the $\zeta$ chain of the CD3 complex as well as Grb2 and SHIP, a phosphatidylinositol phosphatase $(31,32)$. Shc is rapidly phosphorylated in response to TCR crosslinking, facilitating its subsequent association with Grb2 and Sos, an exchange factor for the GTPase Ras, leading to its activation (33). Cbl, a large adapter molecule with $\mathrm{SH} 3$ and $\mathrm{SH} 2$ binding sites as well as its own PTB domain can bind ZAP-70, Lck and Fyn, PI3K, Grb2, and the GTPase activating protein Gap, among others $(11,27,33)$. $\mathrm{Cbl}$ appears to serve a negative regulatory role as $\mathrm{Cbl}$ deficient mice have increased numbers of lymphocytes in which ZAP-70, SLP-76, and LAT are all hyperphosphorylated (11). SLP-76, a cytosolic adapter that is a substrate for ZAP-70 (34), can interact with FYB/SLAP130, a Fyn binding protein (35) as well as two additional adapters, Nck and Gads (36).

\section{Tyrosine Phosphatases}

Analysis of the role of phosphatases in TCR signaling suggests that early $\mathrm{T}$ cell signaling involves a dynamic regulation of tyrosine phosphorylation mediated by the opposing tyrosine kinases and phosphatases (for review, see 24). The transmembrane tyrosine phosphatase CD45 is an important positive regulator of the TCR signaling cascade. CD45 has been shown to dephosphorylate the negative regulatory tyrosine in Src family kinases (phosphorylated by Csk) following TcR stimulation (24). $\mathrm{T}$ cells lacking CD45 display an inability to activate Src family kinases through the TCR (37).

Activation of tyrosine phosphatases (PTPases) may also negatively regulate the 
activation of T cells. SHP-1, a cytoplasmic PTPase, has been shown to bind to and dephosphorylateZAP-70, thereby downregulating the kinase activity of ZAP-70 (38). SHP-1 is absent in motheaten mice that exhibit immune deficiency, autoimmune disease, and a progressive inflammatory disease $(24,39)$. The coreceptor CTLA-4 (discussed further below) is associated with SHP-2, another cytoplasmic tyrosine PTPase related to SHP-1 (40). It is postulated that binding CTLA-4 by its ligands, CD80 (B7.1) and CD86 (B7.2) activates SHP-2 causing tyrosine dephosphorylation of a number of important signaling molecules (41). This suggestion is supported by the observation of hyperactivated PTKs in CTLA4-deficient mice (40).

\section{MAP Kinases}

The activation of the PTKs at the TCR-CD3 complex initiate, at least in part, the activation of the MAP kinase pathway. MAP kinases are serine/threonine kinases that phosphorylate various substrates, including a number of transcription factors. There are three distinct families of MAP kinases: the extracellular signal-regulated kinases (ERKs), the Jun amino-terminal kinases (JNKs), and the p38 MAP kinases. Each MAP kinase family has several members, some with multiple isoforms created by alternative splicing $(42,43)$. Each of these MAP kinases is activated by phosphorylation on both serine (S) or threonine $(\mathrm{T})$ and tyrosine (Y). The dual (S/T and Y) phosphorylation is mediated by a MAP kinase kinase (MKK), an enzyme that in turn requires phosphorylation on serine/threonine for activity. The activation of the MKKs is carried out by upstream MAP kinase kinase kinase (MKKKs) (44). Like the MAP kinases, there are multiple MKKs and MKKKs, each with specificity for a particular downstream substrate. MAP kinase activation by TCR stimu- lation may occur through multiple pathways. As discussed above, phosphorylated adapter molecules may bring the SOS guanine nucleotide exchange factor (GEF) into proximity with Ras, converting the inactive GDPbound Ras into the active GTP-bound form. Active Ras is then able to target Raf, an MKKK, to the membrane where Raf is activated (45) by mechanisms that remain unclear at present. In addition, protein kinase $\mathrm{C}(\mathrm{PKC})$, activated upon TCR stimulation, is able to activate Raf-1 (46). Activated Raf is able to phosphorylate MEK, an MKK that in turn phosphorylates ERK; phosphorylated ERK may translocate to the nucleus (43) where it encounters a number of known substrates, predominantly transcription factors (42). Studies using MEK1 interfering mutants or expression of the ERK-specific MAP kinase phosphatase MKP-1 to inhibit ERK activity demonstrated that ERK kinase activity is necessary for the induction of IL-2 in T lymphocytes (47). IL-2 transcription is regulated by the composite interaction of a number of transcription factors including, NF- $\kappa \mathrm{B}, \mathrm{AP}-1$, NFAT, and Oct-1 $(48,49)$. ERK has been shown to regulate the expression of c-fos, a component of the AP-1 transcription factor, by phosphorylating Elk-1 and/or Sap-1a, both of which may be involved in driving the expression of c-fos (50). Taken together, these experiments have implicated ERK as a regulator of transcription factors vital to IL-2 production.

In addition to the ERK kinase pathway, the TCR has been shown to activate the JNK and p38 MAP kinase pathways $(44,51,52)$. All three MAP kinase families can be stimulated by the TCR alone or in conjunction with costimulation by CD28 (43). Activated JNK can phosphorylate the transcription factor components, ATF-2, c-Jun, and Elk-1, driving transcriptional activity (53); by affecting AP-1 transcriptional activation, JNK and ERK kinases may coordinate to regulate IL-2. Fur- 
thermore, JNK activation by CD28 costimulation is abolished by treatment with cyclosporin $\mathrm{A}$ (CsA), a drug that inhibits activity of the serine-threonine phosphatase calcineurin (54). Activated by calcium influx, calcineurin is critical for the dephosphorylation of the transcription factor NFAT, allowing the translocation of NFAT to the nucleus $(55,56)$. Interestingly, JNK activation by TCR-CD3 stimulation is enhanced significantly by CD28 signaling via the coreceptor while ERK activity is not enhanced by CD28 costimulation (54). The requirement for costimulation appears to vary depending upon the cell line and the state of activation and maturation of the cells (52).

Like JNK activity, CD28 costimulation may strengthen the ability of TCR signaling to activate p38 MAP kinase activity (52). Specific p38 inhibitors and a transgenic mouse expressing a dominant negative p38 mutant have been used to demonstrate preferential regulation of Th1 cytokines by p38 MAP kinase (57).

\section{Phosphoinositide 3-Kinase}

Phosphoinositide 3-kinase (PI3K) refers to a family of lipid kinases capable of phosphorylating lipids at the 3 position of the inositol ring, generating phosphatidylinositol (PI) 3-phosphate [PI(3)P], PI 3,4-bisphosphate (PIP 2 ), or PI 3,4,5-trisphophate $\left(\mathrm{PIP}_{3}\right)(58,59)$. The best characterized member of the family, class I PI3K, is a heterodimer consisting of a p85 targeting subunit containing two SH2 domains and a $110 \mathrm{kDa}$ catalytic subunit (60). Although the actual mechanism of activation for PI3K is unclear, it is likely that the docking of the enzyme onto phosphorylated targets by its $\mathrm{SH} 2$ domains at the plasma membrane allow it to interact with its lipid substrates (61). In T lymphocytes, the phosphorylation of LAT by ZAP-70 may permit the subsequent docking of PI3K to membrane-bound LAT (26).
PI3K has also been shown to interact with GTP-bound Ras, and it is suggested that Ras is downstream of PI3K (62). The significance of this interaction is also not clear, but studies with Ras mutants indicate that Ras activity can apparently reciprocally regulate $\mathrm{PI} 3 \mathrm{~K}$ activity in vivo $(63,64)$.

How PI3K affects downstream events is an area of intense study. Most forms of PI3K possess intrinsic protein kinase activity for which one target is a serine residue within PI3K itself, the specific phosphorylation of which may serve to downregulate its own lipid kinase activity (60). Other substrates, such as the phospholipid products generated by an active PI3K [PI(3)P, $\mathrm{PIP}_{2}, \mathrm{PIP}_{3}$ ] are involved in the regulation of a number of signaling pathways. Several distinct types of domains within signaling proteins have been shown to bind phospholipids. Pleckstrin homology $(\mathrm{PH})$ domains bind both $\mathrm{PIP}_{2}$ and $\mathrm{PIP}_{3}$ phospholipids (65), SH2 domains bind $\mathrm{PIP}_{3}(66)$, and a motif defined by FYVE binds PI(3)P $(67,68)$. A number of signaling proteins such as Vav, Itk, and Akt, involved in T cell activation, contain $\mathrm{PH}$ domains and bind both $\mathrm{PIP}_{2}$ and $\mathrm{PIP}_{3}$ $(1,59)$. Phosphoinositide binding to $\mathrm{PH}$ domains targets the protein to the plasma membrane, bringing it into contact with substrates (69).

Akt, a serine/threonine kinase, is an important effector of PI3K activity. Phospholipid binding to the $\mathrm{PH}$ domain of Akt translocates it to the membrane, bringing it into proximity with PDK1 and PDK2, two kinases necessary for phosphorylating and activating Akt. A central identified target for Akt is glycogen synthase kinase-3 $\beta$ (GSK3- $\beta$ ) involved in the regulation of glycogen synthesis, AP-1 and CREB expression, and function of the APC tumor suppressor $(70,71)$. Akt has also been shown to phosphorylate BAD, a Bcl family member implicated in apoptotic regulation $(72,73)$ and to promote the cell cycle pro- 
gression through regulation of the E2F family of transcription factors $(74,75)$.

The TEC family member Itk and PLC $\gamma$ also possess $\mathrm{PH}$ domains that target the enzyme plasma membrane by binding $\mathrm{PIP}_{3}$. The translocation permits the Itk-like kinase to phosphorylate membrane bound PLC $\gamma$, enhancing its activation. Additionally, both Itk and PLC $\gamma$ are able to be activated directly by the binding of phospholipid, independent of targeting to the membrane (59). Similarly, PI3K-generated phospholipids may regulate the activity of PH-domain containing GEFs such as Vav, the activity of which regulates the function of Rho family GTPases, thereby affects cytoskeletal changes and vesicular trafficking (76).

\section{The Role of Costimulation in $\mathbf{T}$ Cell Activation}

Appropriate $\mathrm{T}$ cell activation and differentiation are not achieved simply by MHCantigen engagement of the TCR alone. There must also be an additional signal provided by a second, nonpolymorphic receptor on the surface of the $\mathrm{T}$ cell, referred to as a costimulatory molecule $(6,77)$. A number of molecules have been reported to exhibit some costimulatory behavior, $\mathrm{CD} 28$ being the most potent and well studied of these. Coengagement of CD28 with the TCR can prevent the induction of $T$ cell anergy or unresponsiveness, which has become one defining criteria for costimulation. It has become clear that the engagement of many different surface receptors, while not preventing anergy in the manner of CD28, may have qualitative effects on the response of a $\mathrm{T}$ cell. Therefore, a brief examination of the role of some of these receptors will serve to allow comparison to the effects of CD7, discussed below.

CD28 is a homodimeric glycoprotein found on most $\mathrm{CD} 4^{+} \mathrm{T}$ cells and about $50 \%$ of $\mathrm{CD} 8^{+}$
$\mathrm{T}$ cells in the human (78), and its expression may be increased upon activation of the T cell. A member of the immunoglobulin gene superfamily, CD28 has a cytoplasmic tail of 41 amino acids that has been shown to bind to PI3K through a phospho-YMNM motif $(79,80)$. CD28 is also able to bind the Lck and Fyn tyrosine kinases $(81,82)$ as well as the TEC family kinase Itk $(82,83)$. Ligation of CD28 leads to activation of a number of signaling molecules including PI3K and the generation of phospholipids $(84,85)$, activation of PLC- $\gamma(7)$, and activation of Akt, the $\mathrm{PIP}_{3}$-dependent serine-threonine kinase described above (86).

CD28 costimulation is critically involved in the induction of IL-2 transcription and translation $(87,88)$. This IL-2 production leads to a robust proliferative response by the $\mathrm{T}$ cell. The failure to produce IL-2 is a major defect in anergic cells, and exogenous IL-2 administration, like CD28 engagement, can block the induction of anergy $(89,90)$. However, CD28 costimulation is also involved in upregulating a number of other cytokines that are important in enhancing not only proliferation but also differentiation and the expression of surface receptors (91). The production of IL-4, IL-5, IL-13, IFN- $\gamma$, TNF- $\alpha$, IL- 8 , and GM-CSF are enhanced by CD28 costimulation (92-96). The particular cytokines produced will vary depending upon the experimental system being studied (97) and the nature of the stimulating ligand (e.g., CD80 or CD86) $(98,99)$.

CD28 has a homolog, cytotoxic T lymphocyte-associated antigen 4 (CTLA-4/CD154), that is not expressed (or only very minimally expressed) on resting T cells. CTLA-4 functions generally as an inhibitor of $\mathrm{T}$ cell activation $(6,100)$. CTLA- 4 is detectable $24 \mathrm{~h}$ after $\mathrm{T}$ cell activation, with slightly higher expression on CD8+ T cells than CD4+ T cells and greater expression on $\mathrm{CD} 4+\mathrm{Th} 2$ cells than on 
CD4+ Th1 cells (6). The Th1 subset of T cells is characterized by the production of IL-2, IFN- $\gamma$, and TNF- $\beta$, cytokines important in cellmediated immunity, whereas Th2 T cells produce IL-4, IL-5, and IL-10, cytokines more critical for a humoral immune response (101). Like CD28, CTLA-4 also binds Src-family tyrosine kinases (102) and contains a phosphotyrosine motif that mediates PI3K binding (103). However, CTLA-4 is able to bind the protein tyrosine phosphatases SHP-1 and SHP-2 $(104,105)$, phosphatases that are the likely effectors of CTLA-4 mediated inhibitory action.

CD28 and CTLA-4 both engage the same pair of ligands, CD80 (B7.1) and CD86 (B7.2) (78). The two B7 family members are expressed on professional APCs macrophages, monocytes, dendritic cells, and B cells as well as some T lymphocytes. CD86 is expressed constitutively and is increased upon activation of the APC, whereas CD80 is expressed on the cell surface basally at low levels and is increased slowly upon activation $(77,97)$. There is evidence to suggest that CD80 and CD86 elicit distinct cellular responses through CD28 engagement and that the phosphorylation state of certain signaling molecules differ after CD80 costimulation compared to that from CD86 (106). Differences in cytokine profiles produced by $\mathrm{CD}^{+} \mathrm{T}$ cells after costimulation by CD80 vs CD86 have been observed, although these differences appear to vary with the experimental systems $(97,99,107)$. The mechanism by which these differing cytokine profiles may be generated is currently under examination.

In addition to preventing anergy, costimulation through CD28 may also regulate apoptotic death initiated by various stimuli (108-112). Stimulation through TCR-CD3, in cell lines and in recently activated peripheral $\mathrm{T}$ cells, can result in activation-induced cell death (AICD), mediated by Fas receptor binding by Fas ligand, itself induced upon
TCR-CD3 stimulation (113). However, there are conflicting reports regarding the ability of costimulation to prevent AICD. CD28 costimulation had no protective effect upon TCR-CD 3 induced AICD in murine Th1 cells (111); experiments performed with a murine T cell hybridoma showed that CD28 costimulation was protective against AICD, apparently by preventing the TCR-CD3 induced upregulation of Fas ligand (109). Human T lymphocytes have also been demonstrated to resist Fas-induced death when costimulated with CD28 (108). IL-2 has been shown to potentiate AICD by upregulating the expression of the Fas ligand (112). AICD, and its potentiation by IL-2, is thought to maintain homeostasis during an immune response and thus prevent overwhelming lymphoproliferation (113).

CD28 engagement may also protect $\mathrm{T}$ cells from death induced via pathways other than AICD. T cell death due to the lack of or withdrawal from required growth factors, often referred to as programmed cell death (PCD), is delayed by CD28 engagement $(111,113)$. Pretreatment of T cells with CD3 and CD28 $\mathrm{mAbs}$ prolongs the survival of T cells that have been subjected to $\gamma$-irradiation compared to CD3 mAb alone (108). The protective effect of CD28 upon PCD appears to be due, at least in part, to the upregulation of $\mathrm{Bcl}-\mathrm{x}_{\mathrm{L}}(108,110)$; a member of the $\mathrm{Bcl}$ family of proteins involved in the regulation of apoptosis (114).

In addition to enhancing cytokine production and inhibiting cell death, engagement of CD28 appears to lower the threshold of engaged TCRs required for activating a $\mathrm{T}$ cell from 8000 to 1000 (115). The engagement of many costimulatory molecules, including CD28, activates the same signaling pathways activated by TCR engagement, suggesting that a principal function of costimulation is quantitative, not qualitative (116). Several signaling molecules, such as JNK, specifically 
require CD28 in order to be activated (54). These examples underscore qualitative differences following delivery of a costimulatory signal (116). In addition, a number of recent studies have revealed that costimulation may regulate subcellular localization and plasma membrane microdomains essential for the initiation of T cell signaling. A structure has been defined at the plasma membrane that is rich in lipids and cholesterol, termed lipid rafts (117), detergent-insoluble glycolipid-enriched membrane microdomains (DIGs), detergent resistant membranes (DRMs), or glycosphingolipid-enriched membrane microdomains (GEMs). In addition to the specialized lipid components, these rafts contain a high concentration of adapter molecules and kinases (118). The ligation of CD28 in conjunction with the TCR induces the raft migration to the area of the engaged TCR (119-121). This aggregation of the signaling molecules in proximity to the TCR in the rafts changes the kinetics of signaling and concentration of relevant molecules at the interface of the $\mathrm{T}$ cell and APC and may, additionally, promote steric changes in the $\mathrm{T}$ cell allowing the interaction with the APC to occur more efficiently for a greater duration (119).

\section{Other Costimulatory Molecules}

Other molecules in addition to CD28 can markedly affect the nature of a $\mathrm{T}$ cell response to antigen. These coreceptors serve to augment or qualitatively modify the response of the $\mathrm{T}$ cell. The number of molecules displaying some degree of costimulatory activity is rapidly growing.

The CD4 and CD8 coreceptor molecules interact with nonpolymorphic regions of $\mathrm{MHC}$ class II and class I molecules, respectively, and have been shown to augment signals from the TCR (122-124). Coligation of either CD4 or CD8 in conjunction with the TCR increases tyrosine phosphorylation induced by TCR engagement alone, in part by activating the associated Lck Src-related kinase (125), resulting in an increased production of IL-2 by the $\mathrm{T}$ cell $(125,126)$. Treatment of activated CD4 ${ }^{+}$ $\mathrm{T}$ cells with anti-CD4 $\mathrm{mAb}$ prior to $\mathrm{CD} 3 \mathrm{stim}-$ ulation can prevent CD3-induced AICD of the $\mathrm{T}$ cell (127). The CD4-mediated protection correlated with the inhibition of Fas ligand upregulation, as had been observed for CD28 costimulation (109). CD2, interacting with its ligands CD58, CD48, and CD59, is another cell surface molecule possessing costimulatory characteristics $(128,129)$. Coligation of CD2 with CD3 has been shown to augment the production of IL-2 in T cells (130) and to enhance responsiveness to IL-12 (1). Moreover, CD2 engagement, in conjunction with the addition of exogenous IL-2, appears able to reverse anergy in T cells (131). Similar to CD28, CD4, and CD8 ligation, CD2 ligation induces an increase in tyrosyl phosphorylation in T cells $(129,132)$. This increase in tyrosyl phosphorylation is effected, at least in part, through the associated Fyn tyrosine kinase (132). Recently, another member of the CD28 family, termed inducible costimulatory molecule (ICOS), has been cloned (133). ICOS does not upregulate IL-2 production but it is a potent, CD28-independent, costimulator of proliferation and increases Th2-type lymphokines including IL-10. Like CTLA-4, ICOS is not constitutively expressed on the cell surface but must be induced by TCR-CD3 stimulation (133). ICOS costimulation regulates both $\mathrm{Th}_{1}$ and $\mathrm{Th}_{2} \mathrm{CD}^{+}$responses, but not $\mathrm{CD} 8{ }^{+}$CTL responses in vivo (134) by interacting with its ligand $\mathrm{B} 7-\mathrm{H}\left(\mathrm{B} 7-\mathrm{RP}_{1}, \mathrm{LICOS}\right)$ $(135,136)$. Stimulation of the OX40 molecule on $T$ cells by its physiological ligand on $B$ cells can enhance proliferation and IL-2 production in T cells. OX40 is a member of the TNF receptor superfamily of genes and, like CTLA-4 and ICOS, is induced upon TCR triggering (137). 
The CD9 surface molecule has the ability to induce proliferation of $\mathrm{T}$ cells in conjunction with TCR-CD3 signals, but, unlike the effect of $\mathrm{CD} 28$, rapidly results in apoptosis of the T cells (138). Costimulation of T cells with an anti-CD5 $\mathrm{mAb}$ can increase IL-2 secretion, activate the PI3 kinase pathway, and induce the phosphorylation of Vav. A dominant negative Rac1 mutant was shown to ablate the CD5-dependent activation of an IL-2 reporter construct, identifying one downstream effector of CD5 signaling (139). Also, CD5 coligation with $\mathrm{CD} 3$ can increase the association of TCR/CD3 with lipid rafts (2). Finally, as discussed below, there are a number of reports describing the costimulatory characteristics of CD7 signaling including effects on IL-2 secretion, proliferation, and the regulation of adhesion (140-142).

\section{Structure and Molecular Associations of CD7}

Biochemical analysis of CD7 employing neuraminidase, endo- $\mathrm{H}$, or endo-F digestion demonstrated that the mature, expressed protein contained sites of $\mathrm{N}$-linked glycosylation. Endo-F treatment reduced the glycoprotein from 40 to $33 \mathrm{kDa}$. Pulse-chase experiments in the presence of tunicamycin revealed a $29 \mathrm{kDa}$ precursor that was processed to a $33 \mathrm{kDa}$ form, strongly suggesting the presence of O-linked glycosylation (143). Western blotting experiments of reduced and nonreduced CD7 immunoprecipitations have demonstrated that CD7 from T cells exists as a homodimer (144).

The cDNA expressing CD7 was cloned from a COS cell expression system by Aruffo and Seed in 1987 (145) using anti-CD7 mAb reactivity to isolate positive clones. The nucleotide sequence of the clone revealed that CD7 was a member of the immunoglobulin superfamily encoding a protein of 240 amino acids with the characteristics of an integral membrane protein (Fig. 2). The first 25 amino acids appeared to encode a signal sequence yielding a final predicted molecular weight of $23 \mathrm{kDa}$ in the absence of posttranslational modification. The extracellular domain was predicted to contain two $\mathrm{N}$-linked glycosylation sites, agreeing with the earlier biochemical characterization of Sutherland et al. (145). Homology of the extracellular domain of CD7 to immunoglobulin family members, including rat $\mathrm{CD} 8$ and the murine $\operatorname{IgG} \kappa$ chain, predicted one immunoglobulin superfamily fold, whereas a 27 amino acid hydrophobic domain was predicted to be the transmembrane region suggesting the final 39 amino acids comprised the cytoplasmic domain. There are two tyrosine residues, two threonine residues, and six serine residues within the cytoplasmic domain of CD7. Orthophosphate-labeled immunoprecipitates of CD7 from HSB-2 cells subjected to phosphoamino acid analysis revealed serine, threonine, and tyrosine phosphorylation. Serine was the predominantly labeled phosphoamino acid and tyrosine the least strongly labeled residue (143).

Like CD28, the cytoplasmic domain of CD7 contains a YXXM sequence that is predicted to be a binding site for the $\mathrm{SH} 2$ domains of the p85 subunit of PI3K (146). The physical association of PI3K with CD7 and the formation of phosphatidylinositol 3,4,5-trisphosphate subsequent to CD7 ligation with antibody has been demonstrated (147-149). Phosphopeptide competition experiments have confirmed that the association of PI3K with $\mathrm{CD} 7$ is mediated by the binding of the $\mathrm{SH} 2$ domains in the $\mathrm{p} 85$ subunit of PI3K to the phosphorylated tyrosine of the YEDM motif in the cytoplasmic domain of CD7 (147,148). The stimulation of PI3K activity appears essential 

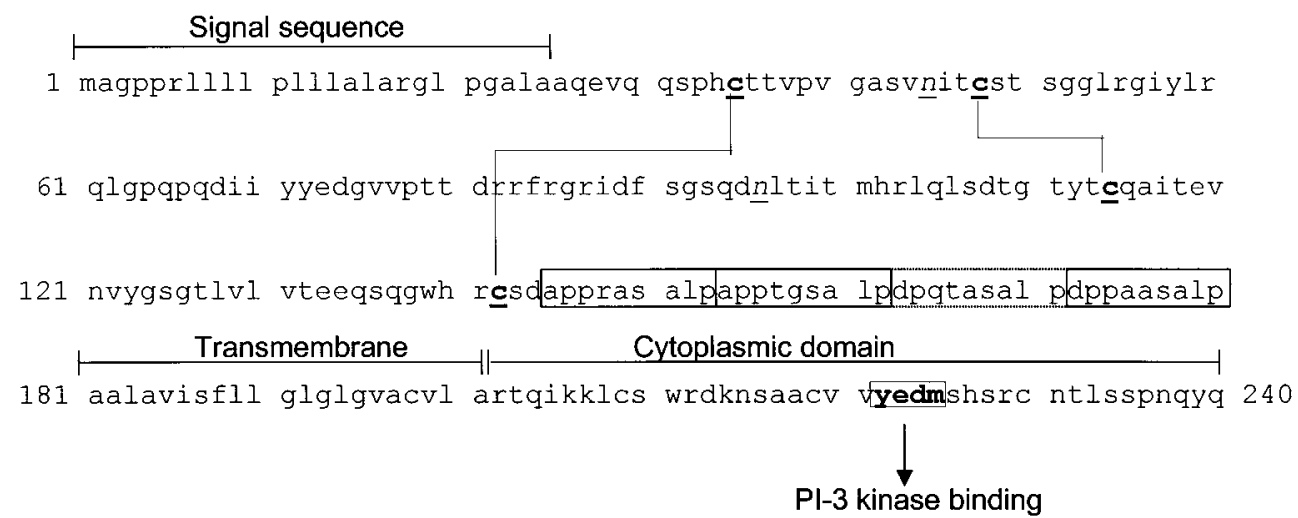

Fig. 2. Predicted sequence of CD7 molecule, a predicted Type 1 membrane protein. Shown is the signal sequence (amino acids 1-25), the mature CD7 protein (amino acids 26-240) containing two potential sites of N-linked glycosylation (amino acids 45 and 96, italics), two putative disulfide bonds (amino acids 35 and 142, 48 and 114, shown in bold). The probable transmembrane (amino acids 181-201) and cytoplasmic (amino acids 202-240) domains are shown. Note four repetitive regions (boxed) (X-P-P-X-A-S-A-L-P) and the $-\mathrm{Y}^{222} \mathrm{EDM}$ - site that, when phosphorylated, is the site of binding of the $\mathrm{p} 85$ subunit of PI-3 kinase.

for inducing CD7-dependent integrin binding as a dominant negative form of the $\mathrm{p} 85 \mathrm{PI} 3 \mathrm{~K}$ subunit abolished the ability of CD7 stimulation to enhance cellular adhesion (147).

Crosslinking of CD7 with mAbs on the surface of Jurkat $\mathrm{T}$ cells induces the coimmunoprecipitation of the CD3 complex as well as the transmembrane tyrosine phosphatase CD45 suggesting that CD7 forms a multimeric complex with CD3 following appropriate T cell stimulation (144). This multimeric complex was shown to contain tyrosine kinase activity (144). Independently, CD7 immunoprecipitated from purified $\mathrm{CD} 4^{+}$human $\mathrm{T}$ cells was shown to associate with a tyrosine kinase activity (150); the tyrosine phosphorylated band in these immunoprecipitates had a relative molecular weight of $80 \mathrm{kDa}$, but remains unidentified (150).

\section{Distribution and Functions of CD7}

CD7 is a $40 \mathrm{kDa}$ glycoprotein found on the surface of T cells and NK cells. CD7 was first identified by mAbs raised against normal human thymocytes $(143,151)$ and T lymphocytes $(152,153)$. CD7 is expressed early on the cell surface during ontogeny of the T cell and expression on many subsets of $\mathrm{T}$ cells is retained throughout maturation (154). CD7 is also expressed on hematopoietic precursor cells capable of differentiating into the B or myeloid lineage. However, both B cells and myeloid cells normally lose CD7 expression during maturation $(155,156)$.

The majority of mature $\mathrm{CD}^{+}$and $\mathrm{CD}^{+}$ peripheral $\mathrm{T}$ cells express CD7. There are, however, small subsets of T cells that lack CD7 on the cell surface. A small population of $\mathrm{CD}^{+}{ }^{+} \mathrm{CD} 45 \mathrm{RA}^{-} \mathrm{CD} 45 \mathrm{RO}^{+}$memory $\mathrm{T}$ cells that lose CD7 expression has been defined in normal human blood (157). Repeated stimulation of $\mathrm{CD}^{+}{ }^{+} \mathrm{CD} 45 \mathrm{RA}^{+} \mathrm{CD} 45 \mathrm{RO}^{-}$cells can induce a switch to $\mathrm{CD}_{45 \mathrm{RO}^{+}}$and cause the loss of CD7 in about $3 \%$ of the total $\mathrm{CD} 4^{+}$cells examined $(158,159)$. Shimizu et al. found that naive $\mathrm{CD} 4^{+} \mathrm{T}$ cells have about twofold higher expression of CD7 than do memory cells (142). 
In addition, a small population of $\mathrm{CD} 7^{+} \mathrm{CD} 3^{-}$ cells was identified in the periphery of normal adult donors (160). These cells were apparently distinct from NK cells because they were able to differentiate into $\mathrm{CD}^{+} \mathrm{T}$ cells upon stimulation with IL-2, phytohemagglutinin (PHA), and irradiated feeder cells (160). Mitogenic stimulation of T cells appears to increase CD7 surface expression $(153,161)$. Experiments with ionophores and dibutyryl cAMP demonstrated that both calcium flux and an increase in cAMP induce the transcription of CD7, whereas anti-CD3 mAb stimulation increases the level of mRNA stability $(161,162)$.

CD7 is absent on the surface of Sezary cells, a form of $\mathrm{CD}^{+}$cutaneous $\mathrm{T}$ cell lymphoma. Moreover, the cutaneous lymphocyte antigen (CLA), which is often found on $\mathrm{T}$ cells in inflammatory skin lesions, is present on a majority of the $\mathrm{CD}^{-}$subset of $\mathrm{CD} 4^{+}$cells expanded after repeated stimulations. This has led to a proposal that the naturally occurring $\mathrm{CD}^{-} \mathrm{T}$ cell population may be precursors of Sezary cells (157). Moreover, the majority of epidermal and dermal $\mathrm{T}$ cells in normal skin lack CD7 expression (163) lending credibility to the hypothesis that $\mathrm{CD}^{-} \mathrm{T}$ cell subsets are precursors of Sezary cells. Recently, however, $\mathrm{T}$ cell clones from Sezary patients were sorted into $\mathrm{CD} 7^{+}$and $\mathrm{CD} 7^{-}$groups and examined for TCR V $\beta$ clonality. The dominant V $\beta$ clones were present in both $\mathrm{CD} 7^{+}$and $\mathrm{CD} 7^{-}$ populations and both CD7 populations expressed identical cytokine profiles (164), challenging the theory that $\mathrm{CD}^{-} \mathrm{T}$ cells comprise the malignant Sezary cell population.

There are some isolated observations that suggest $\mathrm{CD} 7$ expression has a role in diseases other than malignancies. A study of lymphocyte populations in HIV-infected individuals revealed an increase of $\mathrm{CD} 4^{+} \mathrm{CD} 7^{-} \mathrm{T}$ cells from approx $10 \%$ in normal individuals to about $33 \%$ in HIV seropositive patients (165). Oddly, despite the reduction of CD7 levels in HIV infected individuals, anti-CD7 mAbs were shown to prevent the formation of syncytium, necessary for cell free infection and a cytopathic component of in vitro infection, in HIVinfected $\mathrm{T}$ cell lines. These data suggest that expression of CD7 may be an important regulator of HIV infection (166). A single report of a patient with SCID has been described whose only identified phenotypic defect was a lack of CD7 on the SCID T cells (167). No functional connection was made between the lack of CD7 and the immunodeficiency (167).

Engagement of CD7 by anti-CD7 $\mathrm{mAb}$ has both stimulatory and inhibitory effects dependent in part on experimental conditions. Studies using anti-CD7 mAbs in conjunction with anti-CD3 mAb or PMA have shown CD7 to be comitogenic for purified human $T$ cells (140). Anti-CD7 mAb ligation has also been shown to augment the production of IL-2 when used in conjunction with stimulation through the CD3 complex or lectins (141). Conversely, pretreatment with a specific anti-CD7 mAb, RFT2, prevented anti-CD3 antibody-induced proliferation, but not proliferation induced by PHA, ConA, or phorbol esters (168). Additional support for a negative role for CD7 came from the observation that pretreatment of human T cells with anti-CD7 mAbs in the presence of a crosslinking secondary antibody inhibited proliferation induced by PHA treatment or by an allogeneic mixed lymphocyte reaction (MLR) (169). The effect of CD7 mAbs on the inhibition of alloantigen-induced proliferation may be specific to certain subsets of $\mathrm{T}$ cells in that naive $\mathrm{T}$ cells, defined by CD45RA staining, were susceptible to inhibition by anti-CD7 mAbs of alloantigeninduced proliferation whereas CD45RO positive memory cells were not (170).

CD7 has been shown to have a role in regulating integrin-mediated adhesion. Ligation of $\mathrm{CD} 7$ on $\mathrm{CD}^{+}$human $\mathrm{T}$ cells with mAbs 
increased binding to fibronectin, ICAM-1, and VCAM-1 (142). The effect of CD7 ligation on T cell adhesion to ICAM-1 was approximately twofold greater in naive $T$ cells than in memory cells, correlating with the greater expression of CD7 on naive than memory cells, as previously discussed. This effect on adhesion was reduced by treatment with either staurosporine or dibutyryl cAMP, suggesting a role for PKC and cAMP, respectively, in CD7-induced adhesion (142). Further studies have shown that the induction of increased integrin adhesion by $\mathrm{CD} 7$ ligation is abolished by pretreatment of the cells with herbimycin A, a tyrosine kinase inhibitor (150). A role for the lipid kinase PI3K in CD7 signaling has been suggested by the observation that the PI3K inhibitors Wortmannin and LY294002 or a dominant negative form of PI3K inhibited CD7-induced integrin adhesion (147).

CD7 has been shown to stimulate TCR $\gamma / \delta$ $\mathrm{T}$ cells preferentially in one experimental system. CD7 ligation by a particular anti-CD7 $\mathrm{mAb}$ (LAU-A1) induced a calcium flux in three TCR $\gamma / \delta$ T cell lines, but failed to have any effect upon the TCR $\alpha / \beta+\mathrm{T}$ cell line Jurkat or on freshly isolated peripheral blood $\mathrm{T}$ cells, which were predominantly $\alpha / \beta+(171)$. However, this observed discrepancy between TCR $\alpha / \beta$ and TCR $\gamma / \delta$ T cells could have been the result of a specific epitope of CD7 expressed on TCR $\gamma / \delta$ cells and not preferential responsiveness of TCR $\gamma / \delta$ cells to CD 7 ligation. This hypothesis is supported by the isolation of an anti-CD7 mAb that recognizes an epitope on human intraepithelial lymphocytes but not on CD7+ thymocytes (172), demonstrating that there are structurally distinct forms of CD7.

$\mathrm{T}$ cells are not the only hematopoetic cells that are responsive to CD7 signals. Two myeloid progenitor cell lines were found to produce GM-CSF in response to CD7 ligation (173). In addition, CD7 is expressed on virtually all NK cells and has been found to elicit a number of important responses in NK cell activation. Using NK cells purified from human donors, CD7 ligation was seen to stimulate the secretion of IFN- $\gamma$, induce proliferation, enhance cytotoxicity against target cells, generate a calcium flux, and induce the upregulation of a number of cell surface activation markers including CD69 and CD25 $(174,175)$.

A common approach to dissecting the role of a specific gene is to create a transgenic mouse overexpressing the gene of interest or a "knockout" mouse lacking the gene of interest. Mice expressing transgenic human CD7 have yielded little insight into the function of CD7 (176). The human CD7 transgene was expressed at significant levels on B cells and macrophages, expression that differs from its normal expression pattern in humans. The overexpressed human CD7 transgene, however, did not affect hematopoetic development in mice (176). Whether this relates to speciesspecific differences is not clear. The murine CD7 gene predicts a protein product with $45 \%$ homology to the human protein, with one particularly striking divergence from the human CD7 structure. Murine CD7 lacks four proline-rich repeats present in the membrane proximal region of the extracellular domain of human CD7. Although no function has been ascribed to these repeats (177), the structural difference between the human and murine CD7 extracellular domain may provide a possible explanation for the failure of the overexpressed human CD7 to have any significant effect in mice. The murine ligand for CD7 may not be able to recognize and bind the structurally distinct human receptor.

Two different groups have generated mice genetically deficient in murine CD7 (178,179). Bonilla et al. (178) observed essentially no defects in their CD7-deficient mice. Lee et al. (179), however, have found several intriguing changes in mice lacking CD7. The CD7deficient mice of Lee et al. (179) were gener- 
ally in good health but exhibited an increase in thymocyte numbers at 3 months of age. However, thymocyte numbers in these mice appeared normal at all other time points studied, calling into question whether this was an effect attributable to the lack of CD7 or due to some other unknown factor. The mice had normal NK cell numbers and NK cytolytic capacity as measured by chromium release from YAC-1 lymphoma target cells. However, MHC class I-restricted CTL killing, as determined by lysis of OVA-expressing target cells by OVAprimed splenocytes from CD7 deficient mice, was reduced by approx 50\% in the CD7 mutant mice as compared to normal controls (179). The CD7 deficient mice also produced significantly less IFN- $\gamma$ in response to tetanus toxoid administration than did normal controls.

The $\mathrm{CD}^{-/-}$mice were found to be considerably more resistant to death in both low and high dose LPS-induced toxic-shock-syndrome models. Further analysis of these mice revealed that they were also deficient in production of TNF- $\alpha$, IL-6, and IFN- $\gamma$ in response to LPSinduced shock (180). The defect in production of these cytokines appeared to be specific to liver tissue as mRNA levels for TNF- $\alpha$, IL-6, and IFN- $\gamma$ in splenocytes from the same mice did not vary significantly. Furthermore, mRNA levels of IL-18, IL-12, and ICE, all potential inducers of IFN- $\gamma$ production, were not reduced in liver tissue from the $\mathrm{CD}^{-/-}$mice when compared to normal controls. Splenocytes from the $\mathrm{CD}^{-/-}$mice treated with IL-12 and IL-18 were capable of producing normal levels of IFN- $\gamma$.

Further mechanistic studies revealed that the NK1.1 $1^{+} / \mathrm{CD}^{+} \mathrm{T}$ cells from the CD7 deficient mice, known to be involved in the toxic shock response (3), were less than half of the numbers found in the livers of control mice (180). Thus, the absence of CD7 appears to diminish the degree of response to LPS, pos- sibly by preventing the development of a unique subset of $\mathrm{T}$ cells.

\section{CD7 Ligand(s)}

The physiological role of CD7 has remained elusive, a problem compounded by the absence of an identified cognate ligand (Fig. 3). It was once suggested that CD7 was the T cell IgM receptor, but this hypothesis was discredited with the cloning of CD7. Transfection experiments demonstrated that COS cells expressing CD7 remained unable to bind soluble IgM (145). Some investigators have proposed that human CD7 may be a functional homolog of the murine Thy-1 gene, a GPI-linked surface molecule with no transmembrane region, a proposal based on similarity between the genomic organization of introns and exons in the human CD7 and murine Thy-1 genes as well as two small areas of sequence homology within the promoters of each. However, no evidence has suggested similar regulation or function of Thy-1 and CD7, and the cloning of a murine homolog of CD7 further weakens the hypothesis that Thy-1 may be a functional homologue of human CD7.

It has been demonstrated that CD7 is able to bind the plant lectin Concanavalin A (181) as well as the endogenous human lectin, galectin-1 (182). Galectin-1, expressed in a large number of tissues including the thymus, can induce the apoptosis of thymocytes as well as of mature T cells. Thus, galectin- 1 may be an important mediator of immune regulation by serving to delete certain cells from the population. A recent study has shown that a cell line lacking CD7 was not susceptible to galectin-mediated death but could be rendered responsive to galectin-induced apoptosis upon transfection of the CD7 receptor (183). Therefore, CD7, present early in lymphocyte ontogeny, may serve as a component in cell 


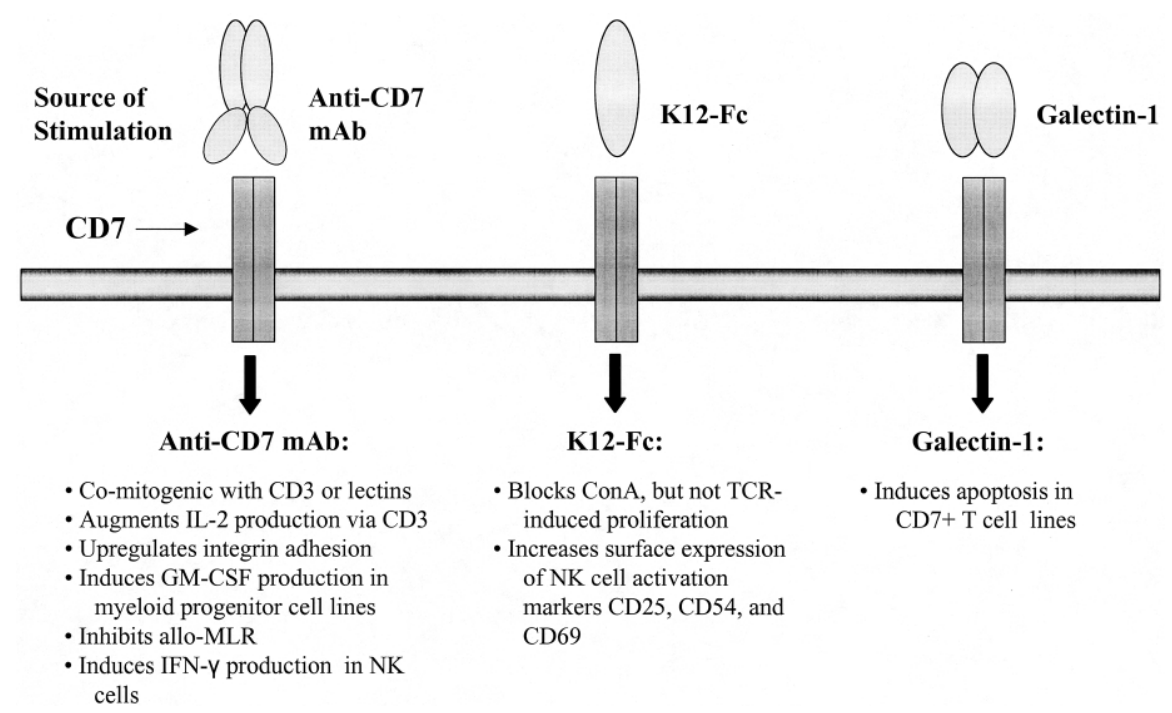

Fig. 3. Functional outcomes of $C D 7$ engagement. Shown are 3 sources of stimulation for CD7, mAbs, the Fc fusion protein of the cognate ligand $\mathrm{K} 12$, and the endogenous human lectin, galectin-1. The experimental results from each method of CD7 stimulation are listed below.

selection mediated by galectin-1. However, since CD7-deficient mice do not have a significant defect in lymphocyte development, CD7 has either a redundant or minor role in directing the development of the $\mathrm{T}$ cell repertoire.

A polypeptide ligand for $\mathrm{CD} 7$ has recently been determined to be the K12 (SECTM1) gene product (184). Investigators used a fusion construct of the K12 extracellular domain linked to the Fc portion of immunoglobulin to probe cells for a ligand; the $\mathrm{CD} 7$ protein was precipitated. K12 exists as both a transmembrane protein as well as a soluble molecule of approx $20 \mathrm{kD}$. Whether $\mathrm{K} 12$ is expressed on the cell surface or retained intracellularly remains unclear (185). K12 is distantly related to the immunoglobulin family and is expressed in nonlymphoid tissues as well as in granulocytes. To date, no lymphoid cell lines have been identified that express K12 mRNA. Interestingly, the gene for K12 is directly upstream of the gene for CD7 on chromosome 17q25, possibly permitting the coordinate regulation of their expression (185).

The secretion of a soluble form of K12 suggests a mechanism for the apparent CD7dependent regulation of the LPS response: LPS-stimulated macrophages may release increased amounts of soluble K12 that bind to and stimulate CD7 signaling, resulting in increased IFN- $\gamma$ production by $\mathrm{T}$ cells. This IFN- $\gamma$ production could then further stimulate macrophages, creating an escalating cycle of cellular activation in the presence of persistence LPS. To date, however, no functional effects of the CD7-K12 interaction have been observed on the murine LPS response. Further exploration of the effects of this natural ligand binding to $\mathrm{CD} 7$ are warranted.

\section{Conclusion}

The activation of the $T$ cell is a complex event, requiring the coordination of a number of external stimuli derived from receptor- 
ligand interactions, soluble mediators, and the microenvironment. These stimuli elicit a complex array of signaling events, coordinately regulated to the strength of antigen engagement. The specific nature of these signals then dictate the production of cytokines, regulation of both surface and intra- cellular molecules that, in turn, affect the character of an immune response. Determining the role of costimulatory and inhibitory surface molecules and the specific intracellular signaling pathways they regulate will further our understanding of the control of the immune response.

\section{References}

1 Qian D, Weiss A: T cell antigen receptor signal transduction. Curr Opin Cell Biol 1997;9(2): 205-212.

2 Wange RL, Samelson LE: Complex complexes: signaling at the TCR. Immunity 1996;5(3): 97-205.

3 BretscherP: The two-signal model of lymphocyte activation twentyone years later. Immunol Today 1992;13(2):74-76.

4 Norment AM, Salter RD, Parham P, Engelhard VH, Littman DR: Cell-cell adhesion mediated by CD8 and MHC class I molecules. Nature 1988;336(6194):79-81.

5 Veillette A, Bookman MA, Horak EM, Samelson LE, Bolen JB: Signal transduction through the CD4 receptor involves the activation of the internal membrane tyrosine-protein kinase p56lck. Nature 1989;338(6212):257-259.

6 Chambers CA, Allison JP: Costimulatory regulation of $\mathrm{T}$ cell function. Curr Opin Cell Biol 1999;11(2):203-210.

7 Ward SG: CD28: a signalling perspective. Biochem J 1996;318(Pt 2):361-377.

8 Ashwell JD, Klausner RD: Genetic and mutational analysis of the T-cell antigen receptor. Annu Rev Immunol 1990;8:139-167.

9 Weissman AM: The T-cell antigen receptor: a multisubunit signaling complex. Chem Immunol 1994;59: 1-18.

10 Cambier JC: Antigen and Fc receptor signaling. The awesome power of the immunoreceptor tyrosine-based activation motif (ITAM). J Immunol 1995;155(7): 3281-3285.
11 Rudd CE: Adaptors and molecular scaffolds in immune cell signaling. Cell 1999;96(1):5-8.

12 Pawson T, Gish GD: SH2 and SH3 domains: from structure to function. Cell 1992;71(3):359-362.

13 Iwashima M, Irving BA, van Oers NS, Chan AC, Weiss A: Sequential interactions of the TCR with two distinct cytoplasmic tyrosine kinases. Science 1994;263(5150): 1136-1139.

14 van Oers NS, Killeen N, Weiss A: Lck regulates the tyrosine phosphorylation of the $\mathrm{T}$ cell receptor subunits and ZAP-70 in murine thymocytes. J Exp Med 1996; 183(3):1053-1062.

15 Shaw AS, Amrein KE, Hammond C, Stern DF, Sefton BM, Rose JK: The lck tyrosine protein kinase interacts with the cytoplasmic tail of the CD4 glycoprotein through its unique amino-terminal domain. Cell 1989;59(4):627-636.

16 Shaw AS, Chalupny J, Whitney JA, Hammond C, Amrein KE, Kavathas P, et al.: Short related sequences in the cytoplasmic domains of CD4 and CD8 mediate binding to the amino-terminal domain of the p56lck tyrosine protein kinase. Mol Cell Biol 1990;10(5):1853-1862.

17 Turner JM, Brodsky MH, Irving BA, Levin SD, Perlmutter RM, Littman DR: Interaction of the unique N-terminal region of tyrosine kinase p56lck with cytoplasmic domains of CD4 and CD8 is mediated by cysteine motifs. Cell 1990;60(5):755-765.

18 Exley M, Varticovski L, Peter M, Sancho J, Terhorst C: Association of phosphatidylinositol 3-kinase with a specific sequence of the $\mathrm{T}$ cell receptor zeta chain is dependent on $\mathrm{T}$ cell activation. J Biol Chem 1994;269(21): 15,140-15,146.

19 Isakov N, Wange RL, Burgess WH, Watts JD, Aebersold R, Samelson LE: ZAP-70 binding specificity to T cell receptor tyrosine-based activation motifs: the tandem $\mathrm{SH} 2$ domains of ZAP-70 bind distinct tyrosine-based activation motifs with varying affinity. J Exp Med 1995;181(1):375-380.

20 Osman N, Lucas SC, Turner H, Cantrell D: A comparison of the interaction of Shc and the tyrosine kinase ZAP-70 with the T cell antigen receptor zeta chain tyrosine-based activation motif. J Biol Chem 1995;270(23): 13,981-13,986.

21 Chan AC, Dalton M, Johnson R, Kong GH, Wang T, Thoma R, et al.: Activation of ZAP-70 kinase activity by phosphorylation of tyrosine 493 is required for lymphocyte antigen receptor function. EMBO J 1995;14(11):2499-2508.

22 Yang WC, Ghiotto M, Barbarat B, Olive D: The role of the Tec protein-tyrosine kinase in $\mathrm{T}$ cell signaling. J Biol Chem 1999;274(2): 607-617.

23 Yang WC, Collette Y, Nunes JA, Olive D: Tec kinases: a family with multiple roles in immunity. Immunity 2000;12(4):373-382.

24 Plas DR, Thomas ML: Negative regulation of antigen receptor signaling in lymphocytes. J Mol Med 1998;76(8):589-595.

25 Liu KQ, Bunnell SC, Gurniak CB, Berg LJ: T cell receptor-initiated calcium release is uncoupled from 
capacitative calcium entry in Itkdeficient T cells. J Exp Med 1998;187(10):1721-1727.

26 Zhang W, Sloan-Lancaster J, Kitchen J, Trible RP, Samelson LE: LAT: the ZAP-70 tyrosine kinase substrate that links T cell receptor to cellular activation. Cell 1998;92(1):83-92.

27 Clements JL, Koretzky GA: Recent developments in lymphocyte activation: linking kinases to downstream signaling events. J Clin Invest 1999;103(7):925-929.

28 Finco TS, Kadlecek T, Zhang W, Samelson LE, Weiss A: LAT is required for TCR-mediated activation of PLCgamma1 and the Ras pathway. Immunity 1998;9(5): 617-626.

29 Zhang W, Irvin BJ, Trible RP, Abraham RT, Samelson LE: Functional analysis of LAT in TCRmediated signaling pathways using a LAT-deficient Jurkat cell line. Int Immunol 1999;11:943-950.

30 Zhang W, Trible RP, Zhu M, Liu SK, McGlade CJ, Samelson LE: Association of Grb2, Gads and phospholipase C- $\gamma 1$ with phosphorylated LAT tyrosine residues. Effect of tyrosine mutations on $\mathrm{T}$ cell antigen receptor-mediated signaling. J Biol Chem 2000;275(30): 23,355-23,361.

31 Ravichandran KS, Lee KK, Songyang Z, Cantley LC, Burn P, Burakoff SJ: Interaction of Shc with the zeta chain of the T cell receptor upon T cell activation. Science 1993;262(5135):902-905.

32 Ravichandran KS, Lorenz U, Shoelson SE, Burakoff SJ: Interaction of Shc with Grb2 regulates association of Grb2 with mSOS. MolCellBiol 1995;15(2):593-600.

33 Pratt JC, Sawasdikosol S, van den Brink MR, Burakoff SJ: Positive and negative signaling pathways. Transplant Proc 1999;31(1-2): 772-774.

34 Jackman JK, Motto DG, Sun Q, Tanemoto M, Turck CW, Peltz GA, et al.: Molecular cloning of SLP76, a 76-kDa tyrosine phosphoprotein associated with Grb2 in T cells. JBiol Chem 1995;270(13): 7029-7032.

35 da Silva AJ, Li Z, de Vera C, Canto E, Findell P, Rudd CE: Cloning of a novel T-cell protein FYB that binds FYN and SH2-domaincontaining leukocyte protein 76 and modulates interleukin 2 production. Proc Natl Acad Sci USA 1997;94(14):7493-7498.

36 Liu SK, Fang N, Koretzky GA, McGlade CJ: The hematopoieticspecific adaptor protein gads functions in T-cell signaling via interactions with the SLP-76 and LAT adaptors. Curr Biol 1999; 9(2):67-75.

37 McFarland ED, Hurley TR, Pingel JT, Sefton BM, Shaw A, Thomas ML: Correlation between Src family member regulation by the protein-tyrosine-phosphatase CD45 and transmembrane signaling through the T-cell receptor. Proc Natl Acad Sci U S A 1993; 90(4):1402-1406.

38 Plas DR, Johnson R, Pingel JT, Matthews RJ, Dalton M, Roy G, et al.: Direct regulation of ZAP-70 by SHP-1 in T cell antigen receptor signaling. Science 1996; 272(5265):1173-1176.

39 Shultz LD, Schweitzer PA, Rajan TV, Yi T, Ihle JN, Matthews RJ, et al.: Mutations at the murine motheaten locus are within the hematopoietic cell protein-tyrosine phosphatase (Hcph) gene. Cell 1993;73(7):1445-1454.

40 Marengere LE, Waterhouse P, Duncan GS, Mittrucker HW, Feng GS, Mak TW: Regulation of T cell receptor signaling by tyrosine phosphatase SYP association with CTLA-4. Science 1996; 272(5265):1170-1173.

41 Saito T: Negative regulation of T cell activation. Curr Op Immunol 1998;10(3):313-321.

42 Garrington TP, Johnson GL: Organization and regulation of mitogenactivated protein kinase signaling pathways. Curr Opin Cell Biol 1999;11(2):211-218.

43 Hardy K, Chaudhri G: Activation and signal transduction via mitogen-activated protein (MAP) kinases in T lymphocytes. Immunol Cell Biol 1997;75(6): 528-545.

$44 \mathrm{Su}$ B, Karin M: Mitogen-activated protein kinase cascades and regulation of gene expression. Curr Op Immunol 1996;8(3):402-411.
45 Genot E, Reif K, Beach S, Kramer I, Cantrell D: p21ras initiates Rac-1 but not phosphatidyl inositol 3 kinase/PKB, mediated signaling pathways in Tlymphocytes. Oncogene 1998;17(13):1731-1738.

46 Kolch W, Heidecker G, Kochs G, Hummel R, Vahidi H, Mischak H, et al.: Protein kinase $\mathrm{C}$ alpha activates RAF-1 by direct phosphorylation. Nature 1993;364(6434): 249-252.

47 Whitehurst CE, Geppert TD: MEK1 and the extracellular signalregulated kinases are required for the stimulation of IL-2 gene transcription in T cells. J Immunol 1996;156(3):1020-1029.

48 Cantrell D: T cell antigen receptor signal transduction pathways. Annu Rev Immunol 1996;14: 259-274.

49 Ullman KS, Northrop JP, Verweij CL, Crabtree GR: Transmission of signals from the Tlymphocyte antigen receptor to the genes responsible for cell proliferation and immune function: the missing link. Annu Rev Immunol 1990;8: 421-452.

50 Marais R, Wynne J, Treisman R: The SRF accessory protein Elk-1 contains a growth factor-regulated transcriptional activation domain. Cell 1993;73(2):381-393.

51 Faris M, Kokot N, Lee L, Nel AE: Regulation of interleukin-2 transcription by inducible stable expression of dominant negative and dominant active mitogenactivated protein kinase kinase kinase in Jurkat T cells. Evidence for the importance of Ras in a pathway that is controlled by dual receptor stimulation. J Biol Chem 1996;271(44): 27,366-27,373.

52 Zhang J, Salojin KV, Gao JX, Cameron MJ, Bergerot I, Delovitch TL: 338 mitogen-activated protein kinase mediates signal integration of TCR/CD28 costimulation in primary murine $\mathrm{T}$ cells. J Immunol 1999;162(7):3819-3829.

53 Smeal T, Binetruy B, Mercola DA, Birrer M, Karin M: Oncogenic and transcriptional cooperation with Ha-Ras requires phosphorylation of c-Jun on serines 63 and 73 . Nature 1991;354(6353):494-496. 
54 Su B, Jacinto E, Hibi M, Kallunki T, Karin M, Ben-Neriah Y: JNK is involved in signal integration during costimulation of T lymphocytes. Cell 1994;77(5): 727-736.

55 Crabtree GR, Clipstone NA: Signal transmission between the plasma membrane and nucleus of T lymphocytes. Annu Rev Biochem 1994;63:1045-1083.

56 Viola JP, Rao A: Molecular regulation of cytokine gene expression during the immune response. JClin Immunol 1999;19(2):98-108.

57 Rincon M, Enslen H, Raingeaud J, Recht M, Zapton T, Su MS, et al.: Interferon-gamma expression by Th1 effector T cells mediated by the p38 MAP kinase signaling pathway. EMBO J 1998;17(10): 2817-2829.

58 Kapeller R, Cantley LC: Phosphatidylinositol 3-kinase. Bioessays 1994;16(8):565-576.

59 Leevers SJ, Vanhaesebroeck B, Waterfield MD: Signalling through phosphoinositide 3-kinases: the lipids take centre stage. Curr Opin Cell Biol 1999;11(2):219-225.

60 Fruman DA, Meyers RE, Cantley LC: Phosphoinositide kinases. Annu Rev Biochem 1998;67: 481-507.

61. Vanhaesebroeck B, Leevers SJ, Panayotou G, Waterfield MD: Phosphoinositide 3-kinases: a conserved family of signal transducers. Trends Biochem Sci 1997; 22(7):267-272.

$62 \mathrm{Hu}$ Q, Klippel A, Muslin AJ, Fantl WJ, Williams LT: Ras-dependent induction of cellular responses by constitutively active phosphatidylinositol-3 kinase. Science 1995;268(5207):100-102.

63 Marte BM, Rodriguez-Viciana P, Wennstrom S, Warne PH, Downward J: R-Ras can activate the phosphoinositide 3-kinase but not the MAP kinase arm of the Ras effector pathways. Curr Biol 1997;7(1):63-70.

64 Rodriguez-Viciana P, Warne $\mathrm{PH}$, Dhand R, Vanhaesebroeck B, Gout I, Fry MJ, et al.: Phosphatidylinositol-3-OH kinase as a direct target of Ras. Nature 1994;370 (6490):527-532.
65 Salim K, Bottomley MJ, Querfurth E, Zvelebil MJ, Gout I, Scaife R, et al.: Distinct specificity in the recognition of phosphoinositides by the pleckstrin homology domains of dynamin and Bruton's tyrosine kinase. EMBO J 1996; 15(22):6241-6250.

66 Rameh LE, Chen CS, Cantley LC: Phosphatidylinositol $(3,4,5) \mathrm{P} 3$ interacts with $\mathrm{SH} 2$ domains and modulates PI 3-kinase association with tyrosine-phosphorylated proteins. Cell 1995;83(5):821-830.

67 Corvera S, Czech MP: Direct targets of phosphoinositide 3-kinase products in membrane traffic and signal transduction. Trends Cell Biol 1998;8(11):442-446.

68 Wiedemann C, Cockcroft S: Vesicular transport. Sticky fingers grab a lipid. Nature 1998;394(6692): 426-427.

69 Hemmings BA: PH domains-a universal membrane adapter. Science 1997;275(5308):1899.

70 Cross DA, Alessi DR, Cohen P, Andjelkovich M, Hemmings BA: Inhibition of glycogen synthase kinase- 3 by insulin mediated by protein kinase B. Nature 1995; 378(6559):785-789.

71 Marte BM, Downward J: PKB/ Akt: connecting phosphoinositide 3-kinase to cell survival and beyond. Trends Biochem Sci 1997; 22(9):355-358.

72 Datta SR, Dudek H, Tao X, Masters S, Fu H, Gotoh Y, et al.: Akt phosphorylation of BAD couples survival signals to the cellintrinsic death machinery. Cell 1997;91(2):231-241.

73 del Peso L, Gonzalez-Garcia M, Page C, Herrera R, Nunez G: Interleukin-3-induced phosphorylation of BAD through the protein kinase Akt. Science 1997;278(5338): 687-689.

74 Brennan P, Babbage JW, Burgering BM, Groner B, Reif K, Cantrell DA: Phosphatidylinositol3-kinase couples the interleukin-2 receptor to the cell cycle regulator E2F. Immunity 1997;7(5):679-689.

75 Brennan P, Babbage JW, Thomas G, Cantrell D: p70(s6k) integrates phosphatidylinositol 3-kinase and rapamycin-regulated signals for
E2F regulation in T lymphocytes. Mol Cell Biol 1999;19(7): 4729-4738.

76 Han J, Luby-Phelps K, Das B, Shu X, XiaY, Mosteller RD, et al.: Role of substrates and products of PI 3-kinase in regulating activation of Rac-related guanosine triphosphatases by Vav. Science 1998; 279(5350):558-560.

77 Greenfield EA, Nguyen KA, Kuchroo VK: CD28/B7 costimulation: a review. Crit Rev Immunol 1998;18(5):389-418.

78 June CH, Bluestone JA, Nadler LM, Thompson CB: The B7 and $\mathrm{CD} 28$ receptor families. Immunol Today 1994;15(7):321-331.

79 Prasad KV, CaiYC, Raab M, Duckworth B, Cantley L, Shoelson SE, et al.: T-cell antigen CD28 interacts with the lipid kinase phosphatidylinositol 3-kinase by a cytoplasmic Tyr(P)-Met-Xaa-Met motif. Proc Natl Acad Sci U S A 1994;91(7):2834-2838.

80 Truitt KE, Hicks CM, Imboden JB: Stimulation of CD28 triggers an association between CD28 and phosphatidylinositol 3-kinase in Jurkat T cells. J Exp Med 1994; 179(3):1071-1076.

81 Hutchcroft JE, Bierer BE: Activation-dependent phosphorylation of the T-lymphocyte surface receptor CD28 and associated proteins. Proc Natl Acad Sci U S A 1994; 91(8):3260-3264.

82 Raab M, Cai YC, Bunnell SC, Heyeck SD, Berg LJ, Rudd CE: p56Lck and p59Fyn regulate CD28 binding to phosphatidylinositol 3-kinase, growth factor receptorbound protein GRB-2, and T cellspecific protein-tyrosine kinase ITK: implications for T-cell costimulation. Proc Natl Acad Sci U S A 1995;92(19):8891-8895.

83 August A, Gibson S, Kawakami Y, Kawakami T, Mills GB, Dupont B: CD28 is associated with and induces the immediate tyrosine phosphorylation and activation of the Tec family kinase ITK/EMT in the human Jurkat leukemic T-cell line. Proc Natl Acad Sci U S A 1994;91(20):9347-9351.

84 Ward SG, Westwick J, Hall ND, Sansom DM: Ligation of CD28 
receptor by $\mathrm{B} 7$ induces formation of D-3 phosphoinositides in $\mathrm{T}$ lymphocytes independently of $\mathrm{T}$ cell receptor/CD3 activation. Eur J Immunol 1993;23(10): 2572-2577.

85 Ueda Y, Levine BL, Huang ML, Freeman GJ, Nadler LM, June CH, et al.: Both CD28 ligands CD80 (CD80) and CD86 (CD86) activate phosphatidylinositol3-kinase, and wortmannin reveals heterogeneity in the regulation of T cell IL-2 secretion. Int Immunol 1995; 7(6):957-966.

86 Parry RV, Reif K, Smith G, Sansom DM, Hemmings BA, Ward SG: Ligation of the T cell co-stimulatory receptor CD28 activates the serinethreonine protein kinase protein kinase B. Eur J Immunol 1997; 27(10):2495-2501.

87 Gimmi CD, Freeman GJ, Gribben JG, Sugita K, Freedman AS, Morimoto C, et al.: B-cell surface antigen $\mathrm{B} 7$ provides a costimulatory signal that induces $\mathrm{T}$ cells to proliferate and secrete interleukin 2. Proc Natl Acad Sci U S A 1991; 88(15):6575-6579.

88 Linsley PS, Brady W, Grosmaire L, Aruffo A, Damle NK, Ledbetter JA: Binding of the $B$ cell activation antigen $\mathrm{B} 7$ to $\mathrm{CD} 28$ costimulates $\mathrm{T}$ cell proliferation and interleukin 2 mRNA accumulation. J Exp Med 1991;173(3): 721-730.

89 Schwartz RH: A cell culture model for T lymphocyte clonal anergy. Science 1990;248(4961): 1349-1356.

90 Schwartz RH: T cell clonal anergy. Curr Op Immunol 1997;9(3): 351-357.

91 Watowich SS, Wu H, Socolovsky M, Klingmuller U, Constantinescu SN, Lodish HF: Cytokine receptor signal transduction and the control of hematopoietic cell development. Annu Rev Cell Develop Biol 1996;12:91-128.

92 de Boer M, Kasran A, Kwekkeboom J, Walter H, Vandenberghe P, Ceuppens JL: Ligation of B7 with CD28/CTLA-4 on T cells results in CD40 ligand expression, interleukin-4 secretion and efficient help for antibody production by $B$ cells. Eur J Immunol 1993;23(12):3120-3125.

93 Minty A, Chalon P, Derocq JM, Dumont X, Guillemot JC, Kaghad $\mathrm{M}$, et al.: Interleukin-13 is a new human lymphokine regulating inflammatory and immune responses. Nature 1993;362 (6417):248-250.

94 Seder RA, Germain RN, Linsley PS, PaulWE: CD28-mediated costimulation of interleukin 2 (IL-2) production plays a critical role in T cell priming for IL-4 and interferon gamma production. J Exp Med 1994;179(1):299-304.

95 Thompson CB, Lindsten T, Ledbetter JA, Kunkel SL, Young HA, Emerson SG, et al.: CD28 activation pathway regulates the production of multiple T-cell-derived lymphokines/cytokines. Proc Natl Acad Sci U S A 1989;86(4): 1333-1337.

96 Wechsler AS, Gordon MC, Dendorfer U, LeClair KP: Induction of IL- 8 expression in T cells uses the CD28 costimulatory pathway. J Immunol 1994;153(6):2515-2523.

97 Schweitzer AN, Sharpe AH: The complexity of the B7-CD28/ CTLA-4 costimulatory pathway. Agents \& Actions-Supplements 1998;49:33-43.

98 Freeman GJ, Boussiotis VA, Anumanthan A, Bernstein GM, Ke XY, Rennert PD, et al.: CD80 and CD86 do not deliver identical costimulatory signals, since CD86 but not CD80 preferentially costimulates the initial production of IL-4. Immunity 1995;2(5):523-532.

99 Kuchroo VK, Das MP, Brown JA, Ranger AM, Zamvil SS, Sobel RA, et al.: CD80 and CD86 costimulatory molecules activate differentially the Th1/Th2 developmental pathways: application to autoimmune disease therapy. Cell 1995;80(5):707-718.

100 Walunas TL, Lenschow DJ, Bakker CY, Linsley PS, Freeman GJ, Green JM, et al.: CTLA-4 can function as a negative regulator of T cell activation. Immunity 1994; 1(5):405-413.

101 Mosmann TR, Coffman RL: TH1 and $\mathrm{TH} 2$ cells: different patterns of lymphokine secretion lead to different functional properties. Annu Rev Immunol 1989;7: 145-173.

102 Miyatake S, Nakaseko C, Umemori H, Yamamoto T, Saito T: Src family tyrosine kinases associate with and phosphorylate CTLA-4 (CD152). Biochem Biophys Res Comm 1998;249(2):444-448.

103 Schneider H, Prasad KV, Shoelson SE, Rudd CE: CTLA-4 binding to the lipid kinase phosphatidylinositol 3-kinase in T cells. J Exp Med 1995;181(1):351-355.

104 Marengere LE, Okkenhaug K, Clavreul A, Couez D, Gibson S, Mills GB, et al.: The SH3 domain of Itk/Emt binds to proline-rich sequences in the cytoplasmic domain of the $T$ cell costimulatory receptor CD28. J Immunol 1997;159(7):3220-3229.

105 Zhang Y, Allison JP: Interaction of CTLA-4 with AP50, a clathrincoated pit adaptor protein. Proc Natl Acad Sci U S A 1997; 94(17):9273-9278.

106 Slavik JM, Hutchcroft JE, Bierer BE: CD80 and CD86 are not equivalent in their ability to induce the tyrosine phosphorylation of CD28. J Biol Chem 1999;274(5): 3116-3124.

107 Lenschow DJ, Walunas TL, Bluestone JA: CD28/B7 system of T cell costimulation. Annu Rev Immunol 1996;14:233-258.

108 Boise LH, Minn AJ, Noel PJ, June $\mathrm{CH}$, Accavitti MA, Lindsten T, et al.: CD28 costimulation can promote $T$ cell survival by enhancing the expression of Bcl-XL. Immunity 1995;3(1):87-98.

109 ColletteY, Razanajaona D, Ghiotto M, Olive D: CD28 can promote $\mathrm{T}$ cell survival through a phosphatidylinositol 3-kinaseindependent mechanism. Eur J Immunol 1997;27(12):3283-3289.

110 Sperling AI, Auger JA, Ehst BD, Rulifson IC, Thompson CB, Bluestone JA: CD28/B7 interactions deliver a unique signal to naive $\mathrm{T}$ cells that regulates cell survival but not early proliferation. J Immunol 1996;157(9):3909-3917.

111 Van Parijs L, Ibraghimov A, Abbas $\mathrm{AK}$ : The roles of costimulation and 
Fas in T cell apoptosis and peripheral tolerance. Immunity 1996 ; 4(3):321-328.

112 Refaeli Y, Van Parijs L, London CA, Tschopp J, Abbas AK: Biochemical mechanisms of IL-2-regulated Fas-mediated T cell apoptosis. Immunity 1998;8(5): 615-623.

113. Van Parijs L, Abbas AK: Homeostasis and self-tolerance in the immune system: turning lymphocytes off. Science 1998;280(5361): 243-248.

114. Adams JM, Cory S: The Bcl-2 protein family: arbiters of cell survival. Science 1998;281(5381): 1322-1326.

115 Viola A, Lanzavecchia A: T cell activation determined by $\mathrm{T}$ cell receptor number and tunable thresholds. Science 1996;273 (5271):104-106.

116 Shaw AS, Dustin ML: Making the $\mathrm{T}$ cell receptor go the distance: a topological view of $\mathrm{T}$ cell activation. Immunity 1997;6(4): 361-369.

117 Simons K, Ikonen E: Functional rafts in cell membranes. Nature 1997;387(6633):569-572.

118 Zhang W, Trible RP, Samelson LE: LAT palmitoylation: its essential role in membrane microdomain targeting and tyrosine phosphorylation during $\mathrm{T}$ cell activation. Immunity 1998;9(2):239-246.

119 Dustin ML, Shaw AS: Costimulation: building an immunological synapse. Science 1999;283(5402): 649-650.

120 Viola A, Schroeder S, Sakakibara Y, Lanzavecchia A: T lymphocyte costimulation mediated by reorganization of membrane microdomains. Science 1999;283(5402): 680-682.

121 Wulfing C, Davis MM: A receptor/cytoskeletal movement triggered by costimulation during T cell activation. Science 1998; 282(5397):2266-2269.

122 Boyce NW, Jonsson JI, Emmrich F, Eichmann K: Heterologous cross-linking of Lyt-2 (CD8) to the alpha beta- $\mathrm{T}$ cell receptor is more effective in $\mathrm{T}$ cell activation than homologous alpha beta-T cell receptor cross-linking. J Immunol 1988;141(9):2882-2888.
123 Owens T, Fazekas de St. Groth B, Miller JF: Coaggregation of the Tcell receptor with $\mathrm{CD} 4$ and other T-cell surface molecules enhances T-cell activation. Proc Natl Acad SciUSA 1987;84(24):9209-9213.

124 Zamoyska R: CD4 and CD8: modulators of T-cell receptor recognition of antigen and of immune responses? Curr Op Immunol 1998;10(1):82-87.

125 Abraham N, Miceli MC, Parnes JR, Veillette A: Enhancement of T-cell responsiveness by the lymphocyte-specific tyrosine protein kinase p56lck. Nature 1991;350 (6313):62-66.

126 Jonsson JI, Boyce NW, Eichmann $\mathrm{K}$ : Immunoregulation through CD8 (Ly-2): state of aggregation with the alpha/beta/CD3 T cell receptor controls interleukin 2dependent T cell growth. Eur J Immunol 1989;19(2):253-260.

127 Oberg HH, Sanzenbacher R, Lengl-Janssen B, Dobmeyer T, Flindt S, Janssen O, et al.: Ligation of cell surface CD4 inhibits activation-induced death of human T lymphocytes at the level of Fas ligand expression. J Immunol 1997;159(11):5742-5749.

128 Bierer BE, Hahn WC: T cell adhesion, avidity regulation, and signaling: a molecular analysis of CD2. Semin Immunol 1993; 5(4):249-261.

129 Holter W, Schwarz M, Cerwenka A, Knapp W: The role of CD2 as a regulator of human $\mathrm{T}$-cell cytokine production. Immunol Rev 1996;153:107-122.

130 Bierer BE, Peterson A, Gorga JC, Herrmann SH, Burakoff SJ: Synergistic $\mathrm{T}$ cell activation via the physiological ligands for CD2 and the T cell receptor. J Exp Med 1988;168(3):1145-1156.

131 Boussiotis VA, Freeman GJ, Griffin JD, Gray GS, Gribben JG, Nadler LM: CD2 is involved in maintenance and reversal of human alloantigen-specific clonal anergy. J Exp Med 1994;180(5): 1665-1673.

132 Lin H, Hutchcroft JE, Andoniou CE, Kamoun M, Band H, Bierer BE: Association of p59(fyn) with the T lymphocyte costimulatory receptor CD2. Binding of the Fyn
Src homology (SH) 3 domain is regulated by the Fyn $\mathrm{SH} 2$ domain. J Biol Chem 1998;273(31): 19,914-19,921.

133 Hutloff A, Dittrich AM, Beier KC, Eljaschewitsch B, Kraft R, Anagnostopoulos I, et al.: ICOS is an inducible T-cell co-stimulator structurally and functionally related to CD28. Nature 1999; 397(6716):263-266.

134 Kopf M, Coyle AJ, Schmitz N, Barner M, Oxenius A, Gallimore A, et al.: Inducible costimulator protein (ICOS) controls T helper cell subset polarization after virus and parasite infection. J Exp Med 2000;192(1):53-61.

135 Abbas AK, Sharpe AH: T-cell stimulation: an abundace of B7s. Nat Med 1999;5(12):1345-1346.

136 Brodie D, Collins AV, Iaboni A, Fennelly JA, Sparks LM, Xu X-N, et al.: LICOS, a primordial costimulatory ligand? Curr Biol 2000;10:333-336.

137 Akiba H, Oshima H, Takeda K, Atsuta M, Nakano H, Nakajima A, et al.: CD28-independent costimulation of T cells by OX40 ligand and CD70 on activated B cells. J Immunol 1999;162(12): 7058-7066.

138 Park CS, Yashiro Y, Tai XG, Toyooka K, Hamaoka T, Yagita H, et al.: Differential involvement of a Fas-CPP32-like protease pathway in apoptosis of TCR/CD9costimulated, naive $\mathrm{T}$ cells and TCR-restimulated, activated T cells. J Immunol 1998;160(12): 5790-5796.

139 Gringhuis SI, de Leij LF, Coffer PJ, Vellenga E: Signaling through CD5 activates a pathway involving phosphatidylinositol 3-kinase, Vav, and Racl in human mature T lymphocytes. Mol Cell Biol 1998;18(3):1725-1735.

140 Carrera AC, Rincon M, SanchezMadrid F, Lopez-Botet M, de Landazuri MO: Triggering of co-mitogenic signals in T cell proliferation by anti-LFA-1 (CD18, CD11a), LFA-3, and CD7 monoclonal antibodies. J Immunol 1988;141(6):1919-1924.

141 Jung LK, Roy AK, Chakkalath HR: CD7 augments T cell proliferation via the interleukin-2 autocrine 
pathway. Cell Immunol 1992; 141(1):189-199.

142 ShimizuY, van Seventer GA, Ennis E, Newman W, Horgan KJ, Shaw $\mathrm{S}$ : Crosslinking of the T cell-specific accessory molecules CD7 and CD28 modulates $\mathrm{T}$ cell adhesion. J Exp Med 1992;175(2):577-582.

143 SutherlandDR, RuddCE, Greaves MF: Isolation and characterization of a human T lymphocyteassociated glycoprotein (gp40). J Immunol 1984;133(1):327-333.

144 Lazarovits AI, Osman N, Le Feuvre CE, Ley SC, Crumpton MJ: CD7 is associated with CD3 and CD45 on human T cells. J Immunol 1994;153(9):3956-3966.

145 Aruffo A, Seed B: Molecular cloning of two CD7 (T-cell leukemia antigen) cDNAs by a COS cell expression system. EMBO J 1987;6(11):3313-3316.

146 Songyang Z, Shoelson SE, Chaudhuri M, Gish G, Pawson T, Haser WG, et al.: SH2 domains recognize specific phosphopeptide sequences. Cell 1993;72(5): 767-778.

147 Chan AS, Mobley JL, Fields GB, Shimizu Y: CD7-mediated regulation of integrin adhesiveness on human $\mathrm{T}$ cells involves tyrosine phosphorylation-dependent activation of phosphatidylinositol 3-kinase. J Immunol 1997; 159(2): 934-942.

148 Lee DM, Patel DD, Pendergast AM, Haynes BF: Functional association of CD7 with phosphatidylinositol 3-kinase: interaction via a YEDM motif. Int Immunol 1996;8(8):1195-1203.

149 Ward SG, Parry R, LeFeuvre C, Sansom DM, Westwick J, Lazarovits AI: Antibody ligation of CD7 leads to association with phosphoinositide 3-kinase and phosphatidylinositol 3,4,5-trisphosphate formation in T lymphocytes. Eur J Immunol 1995;25(2): 502-507.

150 Chan AS, Reynolds PJ, Shimizu Y: Tyrosine kinase activity associated with the CD7 antigen: correlation with regulation of $\mathrm{T}$ cell integrin function. Eur J Immunol 1994; 24(11):2602-2608.

151 Haynes BF, Eisenbarth GS, Fauci AS: Human lymphocyte antigens: production of a monoclonal antibody that defines functional thymus-derived lymphocyte subsets. Proc Natl Acad Sci U S A 1979;76(11):5829-5833.

152 Haynes BF: Human T lymphocyte antigens as defined by monoclonal antibodies. Immunol Rev 1981; 57:127-161.

153 Morishima Y, Kobayashi M, Yang SY, Collins NH, Hoffmann MK, Dupont B: Functionally different T lymphocyte subpopulations determined by their sensitivity to complement-dependent cell lysis with the monoclonal antibody 4A. J Immunol 1982;129(3):1091-1098.

154 Lobach DF, Hensley LL, Ho W, Haynes BF: Human T cell antigen expression during the early stages of fetal thymic maturation. J Immunol 1985;135(3): 1752-1759.

155 Chabannon C, Wood P, TorokStorb B: Expression of CD7 on normal human myeloid progenitors. J Immunol 1992;149(6): 2110-2113.

156 Grumayer ER, Griesinger F, Hummell DS, Brunning RD, Kersey JH: Identification of novel B-lineage cells in human fetal bone marrow that coexpress CD7. Blood 1991;77(1):64-68.

157 Reinhold U, Liu L, Sesterhenn J, Abken H: CD7-negative T cells represent a separate differentiation pathway in a subset of post-thymic helper $\mathrm{T}$ cells. Immunology 1996;89(3):391-396.

158 Akbar AN, Salmon M, Janossy G: The synergy between naive and memory $\mathrm{T}$ cells during activation. Immunol Today 1991;12(6): 184-188.

159 Haynes BF, Denning SM, Singer $\mathrm{KH}$, Kurtzberg J: Ontogeny of T-cell precursors: a model for the initial stages of human T-cell development. Immunol Today 1989; 10(3):87-91.

160 Preffer FI, Kim CW, Fischer KH, SabgaEM, Kradin RL, Colvin RB: Identification of pre-T cells in human peripheral blood. Extrathymic differentiation of CD7+CD3- cells into CD3+ gamma/delta+ or alpha/beta+ T cells. J Exp Med 1989;170(1): 177-190.
161 Ware RE, Haynes BF: T cell CD7 mRNA expression is regulated by both transcriptional and posttranscriptional mechanisms. Int Immunol 1993;5(2):179-187.

162 Rincon M, Tugores A, Lopez-Botet M: Cyclic AMP and calcium regulate at a transcriptional level the expression of the CD7 leukocyte differentiation antigen. JBiol Chem 1992;267(25):18,026-18,031.

163 Davis AL, McKenzie JL, Hart DN: HLA-DR-positive leucocyte subpopulations in human skin include dendritic cells, macrophages, and CD7-negative T cells. Immunology 1988;65(4):573-581.

164 Dummer R, Nestle FO, Niederer E, Ludwig E, Laine E, Grundmann $\mathrm{H}$, et al.: Genotypic, phenotypic and functional analysis of CD4+ CD7+ and CD4+CD7-T lymphocyte subsets in Sezary syndrome. Arch Dermatol Res 1999;291(6): 307-311.

165 Legac E, Autran B, Merle-Beral H, Katlama C, Debre P: CD4+ CD7-CD57+ T cells: a new T-lymphocyte subset expanded during human immunodeficiency virus infection. Blood 1992;79(7): 1746-1753.

166 Sato AI, Balamuth FB, Ugen KE, Williams WV, Weiner DB: Identification of CD7 glycoprotein as an accessory molecule in HIV-1mediated syncytium formation and cellfree infection. J Immunol 1994;152(10):5142-5152.

167 Jung LK, Fu SM, Hara T, Kapoor N, Good RA: Defective expression of $\mathrm{T}$ cell-associated glycoprotein in severe combined immunodeficiency. J Clin Invest 1986;77(3): 940-946.

168 Costantinides Y, Kingsley G, Pitzalis C, Panayi GS: Inhibition of lymphocyte proliferation by a monoclonal antibody (RFT2) against CD7. Clin Exp Immunol 1991;85(1):164-167.

169 Emara M, Sanfilippo F: The inhibition of $\mathrm{T}$ cell proliferative responses by crosslinking $\mathrm{CD} 7$ and IgM-Fc receptors. Cell Immunol 1992;144(1):143-154.

170 Akbar AN, Amlot PL, Ivory K, Timms A, Janossy G: Inhibition of alloresponsive naive and memory $\mathrm{T}$ cells by CD7 and CD25 anti- 
bodies and by cyclosporine. Transplantation 1990;50(5):823-829.

171 Carrel S, Salvi S, Rafti F, Favrot M, Rapin C, Sekaly RP: Direct involvement of CD7 (gp40) in activation of TcR gamma/delta+ T cells. Eur J Immunol 1991;21(5): 1195-1200.

172 Russell GJ, Parker CM, Cepek KL, Brenner MB, Bhan AK: Evidence for a structural difference in the CD7 polypeptide on human thymocytes and intraepithelial lymphocytes defined by a new monoclonal antibody, 3D9. Cell Immunol 1994;154(1):153-165.

173 Hou Z, Leta E, Jung LK: Crosslinking CD7 on myeloblasts results in granulocyte-macrophage colony-stimulating factor production. Blood 1996;88(1):124-129.

174 Rabinowich H, Lin WC, Herberman RB, Whiteside TL: Signaling via $\mathrm{CD} 7$ molecules on human NK cells. Induction of tyrosine phosphorylation and beta 1 integrin-mediated adhesion to fibronectin. J Immunol 1994; 153(8):3504-3513.

175 Rabinowich H, Pricop L, Herberman RB, Whiteside TL: Expression and function of CD7 molecule on human natural killer cells. J Immunol 1994;152(2):517-526.

176 Schanberg LE, Lee DM, Fleenor DE, Ware RE, Patel DD, Haynes BF, et al.: Characterization of human CD7 transgenic mice. J Immunol 1995;155(5):2407-2418.

177 Yoshikawa K, Seto M, Ueda R, Obata Y, Fukatsu H, Segawa A, et al.: Isolation and characterization of mouse CD7 cDNA. Immunogenetics 1993;37(2):114-119.

178 Bonilla FA, Kokron CM, Swinton $\mathrm{P}$, Geha RS: Targeted gene disruption of murine CD7. Int Immunol 1997;9(12):1875-1883.

179 Lee DM, Staats HF, Sundy JS, Patel DD, Sempowski GD, Scearce RM, et al.: Immunologic characterization of CD7-deficient mice. J Immunol 1998;160(12): 5749-5756.

180 Sempowski GD, Lee DM, Scearce RM, Patel DD, Haynes BF: Resistance of CD7-deficient mice to lipopolysaccharide-induced shock syndromes. J Exp Med 1999;189 (6):1011-1016.

181 Leta E, Hou Z, Lederman L, Jung LK: Interaction between the extra- cellular domain of CD7 and concanavalin A: a clue to the identity of the ligand for CD7. Cell Immunol 1996;173(1):15-21.

182 Pace KE, Lee C, Stewart PL, Baum LG: Restricted receptor segregation into membrane microdomains occurs on human T cells during apoptosis induced by galectin-1. J Immunol 1999;163: 3801-3811.

183 Pace KE, Hahn HP, Pang M, Nguyen JT, Baum LG: Cutting edge: CD7 delivers a pro-apoptotic signal during galectin-1-induced T cell death. J Immunol 2000; 165 : 2331-2334.

184 Lyman SD, Escobar S, Rousseau A-M, Armstrong A, Fanslow WC: Identification of $\mathrm{CD} 7$ as a cognate of the human K12 (SECTM1) protein. J Biol Chem 2000;275(5): 3431-3437.

185 Slentz-Kesler KA, Hale LP, Kaufman RE: Identification and characterization of K12 (SECTM1), a novel human gene that encodes a golgi-associated protein with transmembrane and secreted isoforms. Genomics 1998;47: 327-340. 